\title{
Intra-cardiac feticide injection for cervical ectopic pregnancy less than 10 weeks of gestation: A case report and review of literature
}

\author{
Ayman Shehata Dawood ${ }^{1 *}$, Manal Abdraoof Farahat ${ }^{2}$ \\ 1,2Lecturer, Dept. of Obstetrics and Gynaecolog, Tanta University, Tanta, Egypt
}

*Corresponding Author: Ayman Shehata Dawood

Email: ayman.dawood@med.tanta.edu.eg

Received: $4^{\text {th }}$ April, 2019

Accepted: $6^{\text {th }}$ may, 2019

\begin{abstract}
Objective: To report a case of cervical ectopic managed by intra-cardiac injection of potassium chloride to terminate pregnancy.

Design: Case Report.

Patient: A 24-year-old G2P1+0, presented with vaginal bleeding. Cervical pregnancy ( 7 weeks+4 days) was diagnosed by transvaginal ultrasound.

Intervention: Intra-cardiac injection of (KCL) was done plus intra-amniotic injection of methotrexate under ultrasound guidance.

Outcomes: Safe pregnancy termination and uterine preservation.

Results: Pregnancy was terminated successfully, without complications or side effects.

Conclusion: Intra-cardiac injection of KCL appears to be an effective and safe method in termination of cervical ectopic pregnancy less than 10 weeks.
\end{abstract}

Keywords: Cervical ectopic, Intra-cardiac feticide, Potassium Chloride, Methotrexate.

\section{Introduction}

Cervical ectopic pregnancy is a very rare but serious condition owing to the complications related to both condition and its management options. The condition has an incidence between 1:2500 to 1:18000 of pregnancies and less than $1 \%$ of ectopic pregnancies. ${ }^{1}$

Catastrophic complications occur during any attempt to disturb pregnancy by dilatation and curettage leading to severe uncontrollable hemorrhage ending in hysterectomy. ${ }^{2}$

Management was designed to prevent catastrophic complications depending on gestational age, desire to preserve fertility, and hemodynamic stability. Management options include local or systemic methotrexate administration, ligation of descending cervical branches of uterine arteries, cerclage and cervical tamponade balloon. None of these methods proved to be superior to others. Hysterectomy is a curative solution saving patient's life, but not suitable for patient who wish future fertility.,4

\section{Case presentation}

A 24 years old patient G2P1+0 presented with amenorrhea for 3 weeks after a period of irregular bleeding. The patient sought medical advice at primary care hospital with pregnancy test yielding positive result. The patient gave history of rheumatoid arthritis controlled by medications where these medications were reviewed and managed according to pregnancy food and drug administration (FDA) drug categories. The patient was advised to take folate supplementations and investigations were requested including $\mathrm{CBC}$, liver and renal functions.

Two weeks later, the patient came back with vaginal spotting, ultrasound was done at the primary care hospital where gestational sac was seen inside the cervical canal and a fetus of 7 weeks+4 days gestation was seen with evident cardiac pulsation. The patient was referred to a tertiary care Hospital. The first investigation requested after evaluation was $\beta$-hCG level where it was $85829 \mathrm{IU} / \mathrm{ml}$.

Higher consultation of 3 professors was done where they decided to terminate pregnancy in a safe manner with preservation of the uterus as the patient has only one female child. Under general anesthesia, $2 \mathrm{ml}$ of potassium chloride $15 \%$ solution was injected into fetal heart under guidance of transvaginal ultrasonography then aspiration of amniotic fluid then instillation of methotrexate $(1 \mathrm{mg} / \mathrm{kg})$ into gestational sac. The injected dose was $68 \mathrm{mg}$ according to patient's weight. The needle used was that of oocytes retrieval in intra-cytoplasmic sperm injection (ICSI) (16Gauge, single lumen needle). The procedure was illustrated in (Fig.1-4).

Follow up of the patient was done for 3 days at Tanta University Hospital to check any major bleeding and to check $\beta$-hCG level before discharge. No major bleeding was reported and $\beta$-hCG level at discharge was 77065 $\mathrm{IU} / \mathrm{ml}$. The patient was discharged and instructed about danger signs and to come again if any of these signs are present. The return visits were scheduled to be weekly for 4 weeks with new $\beta$-hCG level to be done at each visit then every 2 weeks till the $\beta$-hCG level become negative. Fortunately, no danger signs occurred and $\beta$-hCG level was decreasing steadily. The gestational sac was found collapsed and $\beta$-hCG level was $54487 \mathrm{IU} / \mathrm{ml}$ after 2 weeks of treatment, then the titer became $36549 \mathrm{IU} / \mathrm{ml}$ after another 2 weeks. The level became $5 \mathrm{IU} / \mathrm{ml}$ after another 5 weeks.

The patient received combined oral contraceptives for 3 months later and is doing well. There were no reported complications except for anemia $(\mathrm{Hb}=8.2 \mathrm{gm} / \mathrm{dl})$ managed by I.M iron injection for one month. 


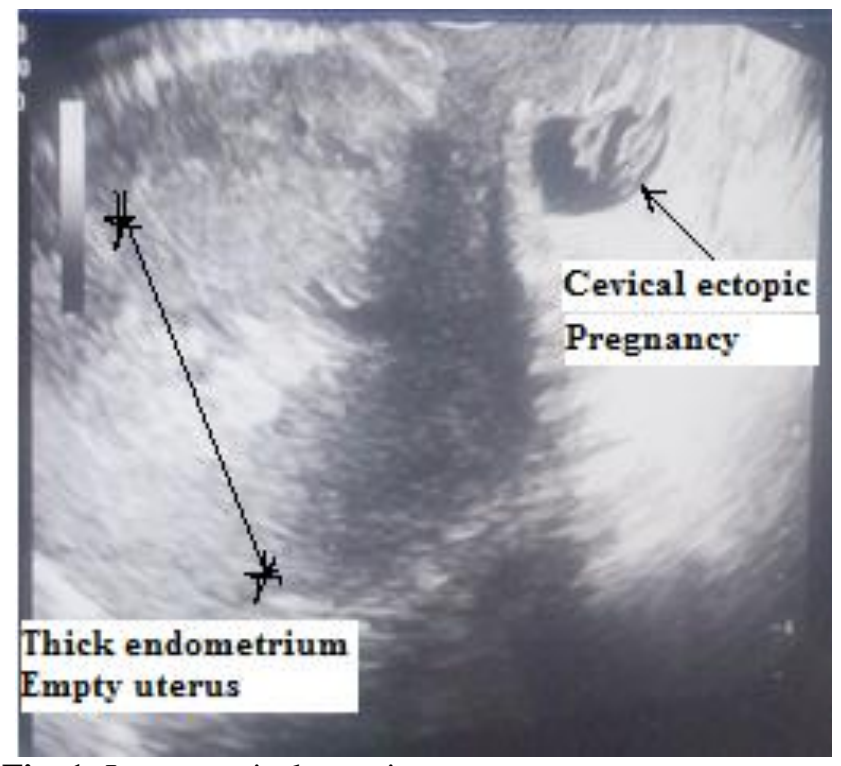

Fig. 1: Intact cervical ectopic pregnancy

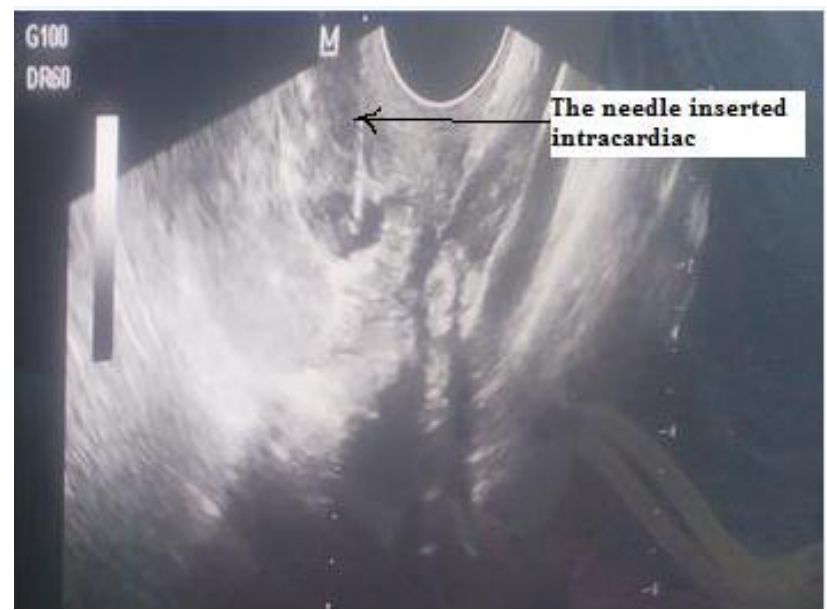

Fig. 2: Intra-cardiac injection of KCL into fetal heart using oocyte retrieval needle

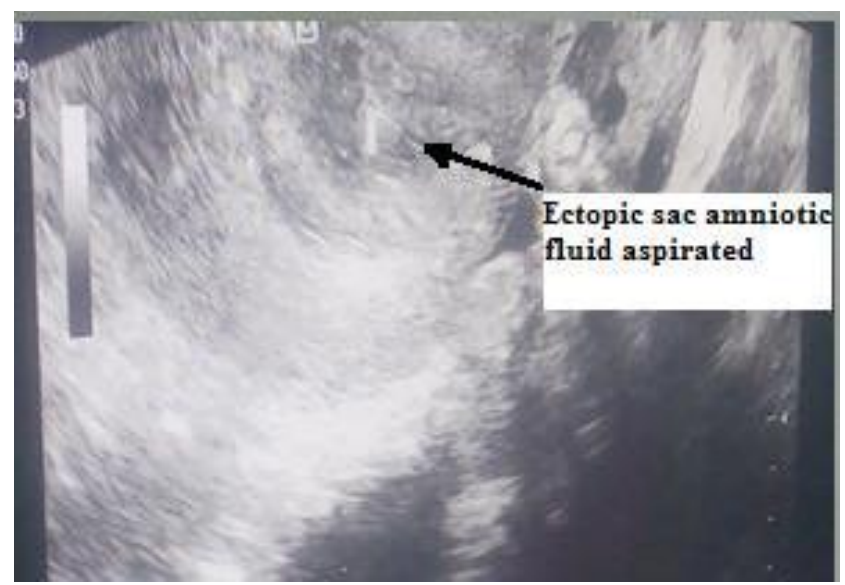

Fig. 3: Aspiration of amniotic fluid

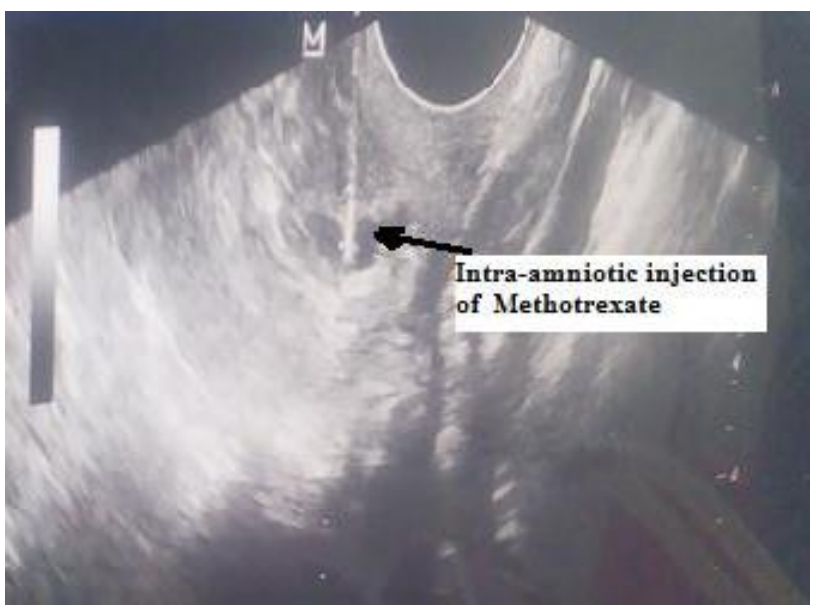

Fig. 4: Instillation of local methotrexate

\section{Discussion}

Cervical ectopic is a very critical obstetric complication if not diagnosed or poorly managed. Severe bleeding may occur jeopardizing patient's life and may necessitate hysterectomy to rescue patient's life. ${ }^{5}$

Many options of treatment were tried in management of cervical ectopic pregnancy but no one proved to be superior to others. Choice of the best treatment modality depends on gestational age, hemodynamic stability and desire of future fertility. ${ }^{6}$ Uludag et al (2017) retrospectively reviewed all cases of cervical ectopic pregnancy managed conservatively either by local and systemic methotrexate in the period from 2010 to 2015. They found that both systemic and local methotrexate was successful regarding maternal morbidity and reproductive function. ${ }^{7}$

In this case report, intra-cardiac injection of KCL 15\% solution caused cessation of cardiac pulsation plus instillation of local methotrexate caused destruction of trophoblastic tissue evidenced by steady drop in $\beta$-hCG level during the follow up period. This modality of treatment is recommended for cervical ectopic less than 10 weeks as it was not associated with any major complications or any danger signs.

\section{Literature Review}

Published studies in the last 10 years were reviewed on Google Scholar, Pubmed, Medline, Researshgate and Clinical key in the period from January, 1, 2009 to October, 31, 2018.

The included studies were that written in English, full text, and addressing local management of cervical ectopic less than 10 weeks, in the last 10 years. The studies found were either retrospective, case reports or case series. The reported studies were shown in table 1 . 
Table 1: Relevant studies in the literature review

\begin{tabular}{|c|c|c|c|c|c|c|c|}
\hline Author & year & $\begin{array}{c}\text { Patient } \\
\text { age }\end{array}$ & $\begin{array}{c}\text { Gestational } \\
\text { age }\end{array}$ & $\begin{array}{c}\beta-H C G \text { prior to } \\
\text { treatment }\end{array}$ & $\begin{array}{c}\text { Method used for } \\
\text { management }\end{array}$ & Complications & $\begin{array}{c}\text { Duration till } \\
\text { negative } \beta \text {-HCG }\end{array}$ \\
\hline $\begin{array}{c}\text { Palshetkar } \\
{[15]}\end{array}$ & 2009 & 32 & 5-6 weeks & $502 \mathrm{IU} / \mathrm{ml}$ & $\begin{array}{l}\text { Systemic MTX then } \\
\text { Local MTX }\end{array}$ & $\begin{array}{c}\text { Vaginal } \\
\text { bleeding +UAE }\end{array}$ & 3 months \\
\hline $\begin{array}{c}\text { Moon } \\
{[12]}\end{array}$ & 2010 & 41 & $\begin{array}{c}6 w k s+4 \\
\text { days }\end{array}$ & $24,076 \mathrm{mIU} / \mathrm{mL}$ & Local MTX & $\mathrm{NM}$ & 3 weeks +3 days \\
\hline $\begin{array}{c}\text { Pereira } \\
\text { [13] }\end{array}$ & 2013 & 33 & NM & NM & $\begin{array}{l}\text { Local KCL, } \\
\text { systemic } \\
\text { UAE }\end{array}$ & $\begin{array}{c}\text { Acute } \\
\text { hemorrhage }\end{array}$ & 3 months \\
\hline $\begin{array}{c}\text { Zakaria } \\
{[14]}\end{array}$ & 2011 & 35 & 7 weeks & $130,464 \mathrm{mIU} / \mathrm{mL}$ & $\begin{array}{l}\text { Systemic MXT with } \\
\text { or without UAE and } \\
\text { local }(\mathrm{KCl} \text {. }\end{array}$ & NM & NM \\
\hline $\begin{array}{c}\text { Begum } \\
{[8]}\end{array}$ & 2012 & 26 & 6 weeks & $12,785 \mathrm{mIU} / \mathrm{ml}$ & $\begin{array}{l}\text { Systemic } \\
\text { MTX+Misoprostol }\end{array}$ & $\begin{array}{c}\text { Severe } \\
\text { hemorrhage }\end{array}$ & 1 month \\
\hline $\begin{array}{c}\text { Šijanović } \\
{[10]}\end{array}$ & 2014 & 31 & 5 weeks & $16553.5 \mathrm{IU} / \mathrm{L}$ & $\begin{array}{l}\text { Local } \\
\text { MTX+hysteroscopy }\end{array}$ & Remanaents & 40 days \\
\hline $\begin{array}{c}\text { Murji } \\
{[11]}\end{array}$ & 2015 & 34 & 7 weeks & $11300 \mathrm{IU} / \mathrm{L}$ & Systemic MTX & $\begin{array}{l}\text { Vaginal } \\
\text { bleeding }\end{array}$ & 26 days \\
\hline $\begin{array}{c}\text { Prameela } \\
\text { [2] }\end{array}$ & 2016 & 25 & 8 weeks & $\begin{array}{c}85860 \\
\mathrm{mIU} / \mathrm{ml}\end{array}$ & $\begin{array}{l}\text { MTX+ Mefiprestone } \\
\text { +Curettage+Balloon } \\
\text { tamponade }\end{array}$ & $\mathrm{NM}$ & NM \\
\hline $\begin{array}{c}\text { Sardo } \\
{[9]}\end{array}$ & 2017 & 36 & 5 wks+5days & $19352 \mathrm{mUI} / \mathrm{mL}$. & $\begin{array}{lr}\text { systemic and local } \\
\text { MTX therapy } \\
\text { combined with } \\
\text { hysteroscopic } \\
\text { resection. }\end{array}$ & NM & 1 month \\
\hline $\begin{array}{c}\text { Uludag } \\
\text { [7] }\end{array}$ & 2017 & $23-40$ & $\begin{array}{c}\text { 6wks- } \\
8 w k s+2 \text { days }\end{array}$ & $\begin{array}{c}29706.9 \\
\pm 19695.2 \mathrm{mIU} / \mathrm{ml}\end{array}$ & $\begin{array}{l}\text { Local and systemic } \\
\text { MTX }\end{array}$ & $\begin{array}{l}\text { oral ulceration } \\
\text { in systemic } \\
\text { MTX and } \\
\text { severe } \\
\text { hemorrhage in } \\
\text { local MTX }\end{array}$ & $8.8 \pm 3.6$ weeks \\
\hline
\end{tabular}

WK: week, MXT: methotrexate, KCL: potassium chloride, UAE: uterine artery embolization, NM: not mentioned,

The age of cases ranges from $25-41$ years, the gestational age ranged from 5 weeks to 8 weeks +2 days. The $\beta$-HCG prior to treatment was variable ranged from $512 \mathrm{mIU} / \mathrm{ml}$ to $130,464 \mathrm{mIU} / \mathrm{mL}$. The methods used for termination were local injection of methotrexate or KCL with or without systemic methotrexate and other methods to control bleeding like uterine artery embolization cervical tamponade and hysteroscpic resection of gestational remnants. The main reported complication is vaginal bleeding managed by additional measures mentioned before. The time needed till negative $\beta-\mathrm{HCG}$ ranged from 3 weeks +3 days to 3 months.

\section{Conclusions}

Intra-cardiac injection of KCL into fetal heart plus instillation of intra-amniotic methotrexate leads to destruction of trophoblastic tissue evidenced by steady drop of $\beta$-HCG levels. This method was found to be safe and not associated by any major complication and effective in preservation of the uterus.

\section{Acknowledgement}

All thanks go to Professor Hesham A. Salem for his great help and assistance in operating this case and for his continuous support and guidance.

\section{Conflict of Interest: None.}

\section{References}

1. Youssef HM, Emam M, Zayed A. "Conservative management of 14 weeks cervical ectopic pregnancy: Case report" Middle East Fertil Soc J 2016;21:4:281-4

2. Prameela RC, Dev SV. "Cervical ectopic pregnancy: 10 year experience at tertiary care hospital and current literature review" Int J Reprod Contracept Obstet Gynecol 2016;5:73442.

3. Lin EP, Bhalt S, Dogra VS. "Diagnostic clues to ectopic pregnancy". Radiographics 2008;28(6):1661-75.

4. Friederike Hoellen, Klaus Diedrich, Christine Dittmer, Katharina Kelling \& Michael K Bohlmann. "Therapeutic management of cervical ectopic pregnancy". Expert Rev Obstet Gynecol 2011;6:1:85-92. DOI: 10.1586/eog.10.67

5. Chang HC, Chiu TH, Lo LM. "Early Cervical Ectopic Pregnancy: A Case Report and Review of the Literature". $J$ Med Ultrasound 2014;22(2):117-9.

6. Samal SK, Rathod S. "Cervical ectopic pregnancy". J Nat Sci Biol Med 2015;6(1):257.

7. Uludag SZ, Kutuk MS, Aygen EM, Sahin Y. "Conservative management of cervical ectopic pregnancy: Single-center experience". J Obstet Gynaecol Res 2017;43(8):1299-1304. doi: 10.1111/jog.13362.

8. Begum J, Begum SN, Ara R, Nargis SF. "A Case of Cervical Ectopic Pregnancy". Bangladesh J Obstet Gynaecol 2012;27(1):31-5.

9. Sardo AD, da Cunha Vieira M, Laganà AS, Chiofalo B, Vitale SG, Scala M, De Falco M, Nappi C, Catena U, Bifulco G. 
"Combined systemic and hysteroscopic intra-amniotic injection of methotrexate associated with hysteroscopic resection for cervical pregnancy: A cutting-edge approach for an uncommon condition". Eurasian J Med 2017;49(1):66.

10. Šijanović S, Vidosavljević D, Topolovec Z, Milostić-Srb A, Mrčela M. "Management of cervical ectopic pregnancy after unsuccesful methotrexate treatment". Iranian J Reprod Med 2014;12(4):285

11. Murji A, Garbedian K, Thomas J, Cruickshank B.

"Conservative management of cervical ectopic pregnancy". $J$ Obstet Gynaecol Can 2015;37:11:1016-20.

12. Moon HS, Hyun JH, Kim KS, Kim HJ, Moon SE, Koo JS. "Use of Tuohy needle for intraamniotic methotrexate injection through the cervical canal in a cervical pregnancy after failure of systemic methotrexate treatment". Am J Obstet Gynecol 2010;202(5):e4-6.
13. Pereira N, Grias I, Foster SE, Della Badia CR. "Acute hemorrhage related to a residual cervical pregnancy: management with curettage, tamponade, and cerclage". $J$ Minim Invasive Gynecol 2013;20(6):907-11.

14. Zakaria MA, Abdallah ME, Shavell VI, Berman JM, Diamond MP, Kmak DC et al. "Conservative management of cervical ectopic pregnancy: utility of uterine artery embolization". Fertil Steril 2011;95(3):872-6.

15. Palshetkar N, Pai H, Bansal B. "Cervical Ectopic Pregnancy". J South Asian Federation Obstet Gynecol 2009;1(1):40-1.

How to cite this article: Dawood AS, Farahat MA, Intracardiac feticide injection for cervical ectopic pregnancy less than 10 weeks of gestation: A case report and review of literature Indian J Obstet Gynecol Res 2019;6(2):233-236. 